\title{
Preliminary Assessment of Ground Water Quality using Water Quality Index near Landfill Site: A Case Study of Ghazipur, Delhi
}

\author{
Priyanka Kumari ${ }^{1}$, Amarjeet Kaur ${ }^{2 *}$, N. C. Gupta ${ }^{3}$ and D. K. Chadha ${ }^{4}$ \\ ${ }^{1} \mathrm{Ph} . \mathrm{D}$. Scholar, University School of Environment Management, Guru Gobind Singh Indraprastha University, \\ Sector 16C, Dwarka, New Delhi 110078, India. (priyanka0645@gmail.com) \\ ${ }^{2 *}$ Professor, University School of Environment Management \& Director, Centre for Disaster Management \\ Studies, Guru Gobind Singh Indraprastha University, Sector 16C, Dwarka, New Delhi 110078, India. \\ (amarjeet_ip@yahoo.com) \\ ${ }^{3}$ Professor \& Dean, University School of Environment Management, Guru Gobind Singh Indraprastha \\ University, Sector 16C, Dwarka, New Delhi 110078, India.(ncgupta.ip@gmail.com) \\ ${ }^{4}$ Former Chairman, Central Ground Water Authority, Government of India and President, Global \\ Hydrogeological Solutions, Delhi, India.(devinderchadha27@gmail.com)
}

\begin{abstract}
The aim of this study is to assess the groundwater quality with the help of water quality index (WQI) and its suitability for human consumption in the residential neighborhood adjacent to Ghazipur landfill site. For the purpose of study, twenty ground water samples were collected within $2 \mathrm{~km}$ radius of landfill-site (from the periphery of landfill) during post monsoon (November 2016) and pre monsoon season (June 2017). Each of the samples were analyzed and compared with Bureau of Indian Standards (BIS) drinking water standards. Mainly 8 parameters viz. $\mathrm{pH}$, total dissolved soild, total hardness; total alkalinity, fluoride, nitrate, chloride and iron were selected to determine the WQI. The WQI of pre monsoon groundwater samples ranged from $49.30(G W 2)$ to 244.83 (GW10) whereas the WQI of post monsoon groundwater samples ranged from 36.06 (GW17) to 239.40 (GW10). It has been found that about 65 percent of sampling locations represents poor quality of groundwater, whereas 20 percent of sampling locations had very poor quality of groundwater. The higher WQI value has been found due to increased concentration of iron, nitrate, total dissolved solids, hardness, fluorides, in the groundwater. The results indicate that there are significant seasonal variations during Pre and Post Monsoon season and contamination level was very high in most of the ground water samples. The results of the present study clearly indicate that the groundwater near landfill site requires adequate treatment before its utilization for human consumption.
\end{abstract}

Keywords: Groundwater pollution, Landfill site, Municipal solid waste, Water Quality Index (WQI).

\section{Introduction}

India is a rapidly growing developing country resulting into the heaps of municipal solid waste (MSW). According to census of India (2011), Delhi is a second most populated city of India with the population of 1.67 crore and expected to generate about 7000 metric tonnes of waste daily. The per capita generation of solid waste is ranging from $200 \mathrm{gms}$ to $600 \mathrm{gms}$ per day depending upon the economic status of the community. It is mainly produced from residential, commercial, and agricultural sources as direct consequences of human activities. Unfortunately, landfill has been used most consistently and the ultimate destiny of MSW disposal without following proper scientific methods (Bhide et al., 1998; Longe et al., 2010). Though landfills emerge as the cost 
effective and easy way to dispose the MSW, it has been also identified as one of the major threats to the contamination of groundwater resources.

Lack of proper waste management practices and its implementation is the major problem behind MSW disposal. After disposal, it goes through various physico-chemical and biological changes. The combination of degraded organic fraction of the wastes and percolating rainwater lead to the generation of a highly concentrated complex liquid called leachate (Kurniawan et al., 2006). Leachate percolates through soil and gradually accumulates at the bottom of landfill, and finally joins the aquifer (Mor et al., 2006). Areas near by landfill have greater possibility of groundwater contamination due to leachate percolation. Such contaminated groundwater and its frequent use in several domestic purposes possess substantial risk to human health and natural environment (Jha et al., 2003; Taylor et al., 2006). It has been confirmed under various research studies that there is strong relation between landfill leachate and groundwater and surface water contamination (Abu-Rukah et al., 2001; Mor et al., 2006). According to WHO (World Health Organization), about $80 \%$ of disease is mainly caused due to use of contaminated water. Once the groundwater is contaminated, it is very difficult to restore its quality. Therefore, it is required to strictly monitor the quality of groundwater regularly and to find the ways to protect from further contamination. Water Quality Index (WQI) is the most effective tool to communicate the water quality information in a simpler way to the concern people and policy makers too (Sharma et al., 2011; Sebastian et al., 2013). Thus, WQI is calculated to know the suitability of groundwater for human consumption.

The objective of the study was to assess the groundwater quality and its suitability for human consumption in the residential neighborhood adjacent to landfill site with the help of WQI.

\subsection{Study Area}

The study area is Ghazipur Landfill site, which is situated in East Delhi, India. It is located at the latitude of $28^{\circ} 37^{\prime} 28^{\prime \prime} \mathrm{N}$ to $77^{\circ} 19^{\prime} 41^{\prime \prime} \mathrm{E}$ longitude with an area of approximately $(3 \times 105 \mathrm{~m} 2) 29.62$ hectares (situated near National Highway 24). It is operational since the year 1984. The landfill receives on an average of 2200-2500 MT of waste daily from the entire East Delhi. The average height of waste is approximately $25 \mathrm{~m}$. However at some places, it has crossed the height of $50 \mathrm{~m}$. The study area is characterized by alluvial formation and quartzite hard rock at greater depth of approximately $100 \mathrm{~m}$ below ground level (bgl). The nearby residential area within the radius of $1 \mathrm{~km}$ is densely populated.

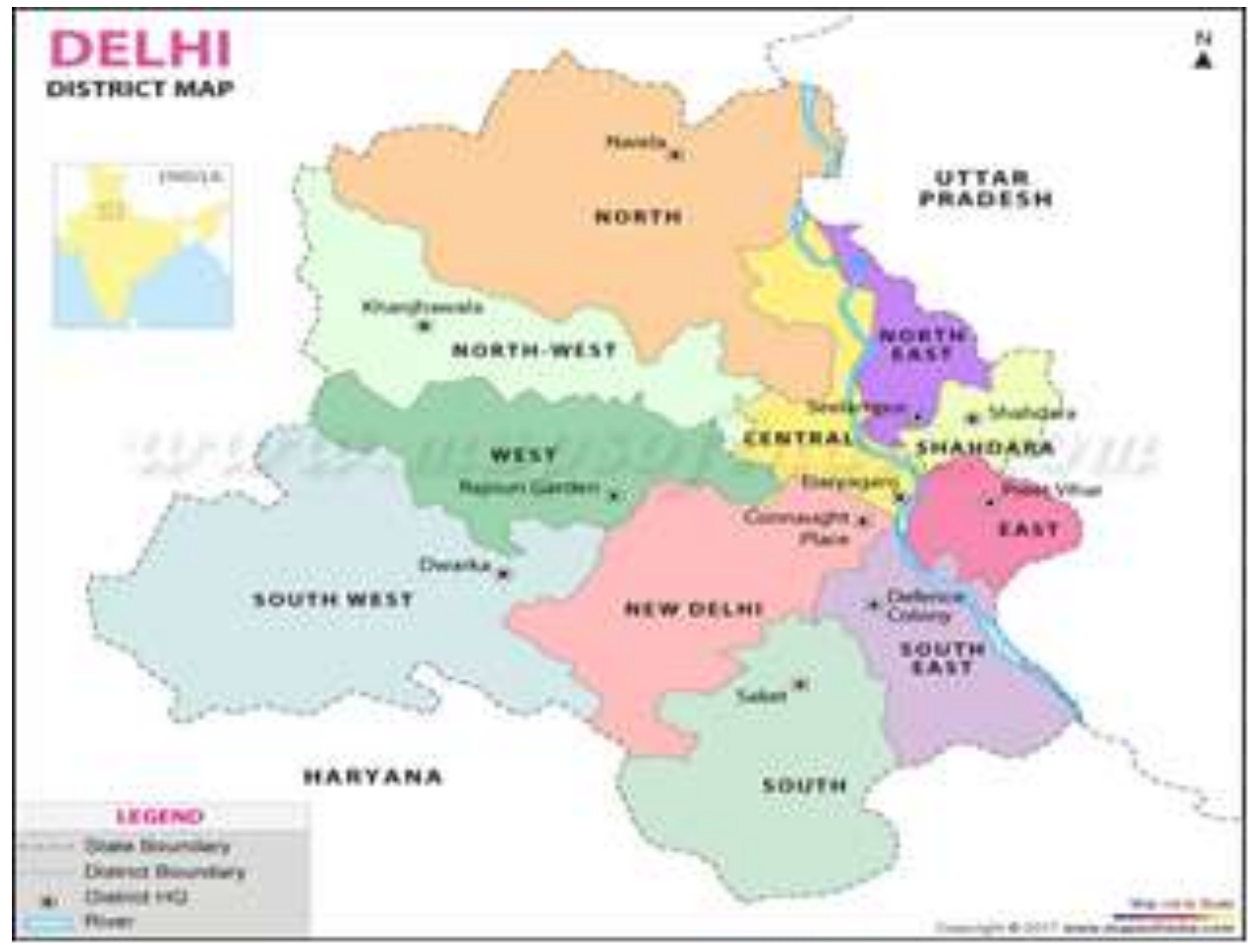




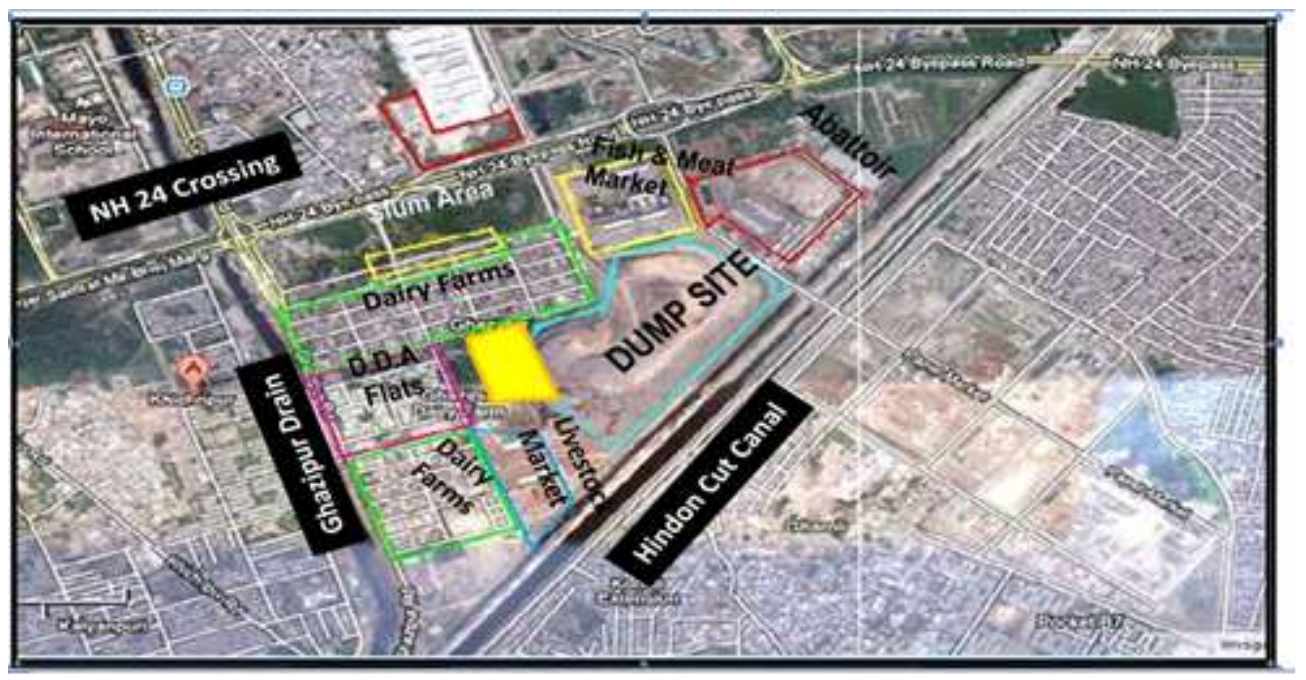

Fig.1: Ghazipur Landfill Site in Delhi (Source: Babbar P., 2015)

\section{Hydrogeological Frame-Work of Ghazipur Landfill Site}

Occurrence and movement of groundwater is majorly affected by hydrogeology of the site. Therefore, detailed hydrogeology of landfill site is required to be explained to understand the movement of leachate into the groundwater and further its contamination. At Ghazipur landfill site, the leachate has been infiltrating into the sub-soil strata since long. Uncontaminated aquifers may exist around the landfill site due to presence of thick clay layer or occurrence of confined sources.

The strata below the landfill site are mainly consisting of about $134 \mathrm{~m}$ thick quaternary alluvium, weathered and fractured quartzite thereafter. To study the nature of aquifer material and its characters, Central Ground Water Board (CGWB) has constructed a number of shallow and deep piezometers as well as exploratory tube wells in the region of the Ghazipur SLF. Lithological details of piezometers at shallow $(15 \mathrm{~m})$ and deeper depth $(134 \mathrm{~m})$ constructed by CGWB have been summarized in Table1 and 2.

TABLE I: Detail of Aquifer Material (15m shallow piezometer of SLF)

\begin{tabular}{|l|l|c|l|}
\hline Sl. No & \multicolumn{1}{|c|}{ Location } & Granual zones encountered (m bgl) & \multicolumn{1}{|c|}{ Lithology } \\
\hline 1 & SLF Office-50 m & $7-12$ & Sand \\
& north of SLF site office & $12-15$ & Sand with Kankars \\
\hline 2 & Poultry Farm-50 m & $4-15$ & Silty clay with kankars \\
\hline 3 & Bio-gas plant-50 m & $4.5-12$ & Sand with silt \\
& west to landfill border & $12-15$ & Clay and kankars \\
\hline
\end{tabular}

TABLE II: Lithological Data of Fish Market, Ghazipur (134 m depth)

\begin{tabular}{|c|c|l|}
\hline Depth range in m bgl & Thickness $(\mathbf{m})$ & \multicolumn{1}{|c|}{ Lithological detail } \\
\hline $0.00-14.45$ & 14.45 & Light yellow clay with minor coarse to gravel size kankar \\
\hline $14.45-21.35$ & 6.90 & Sand with clay silt admixed with fine sand and kankars \\
\hline $21.35-24.13$ & 2.78 & Gravel and kankar with minor silt and fine Sand \\
\hline $24.13-34.10$ & 9.97 & Silty clay with traces of kankar \\
\hline $34.10-41.89$ & 7.79 & Gravel with minor silt and fine sand \\
\hline $41.89-51.46$ & 9.57 & Sand fine-grained along with tracers of gravel \\
\hline $51.46-65.10$ & 13.64 & Clay with silt \\
\hline $65.10-131.55$ & 66.45 & Sticky clay \\
\hline $131.55-134.55$ & 3.00 & Gravel with fine sand \\
\hline
\end{tabular}

The above observations and inferences obtained from the details of lithology data are represented through the sub-surface geological cross section (Figure 2). It shows that the area consists of a mixture of fine and 
medium sand with coarse hard kankar up to a depth of $50 \mathrm{~m}$ bgl. Hence, it may be inferred as single aquifer system of $50 \mathrm{~m}$ depth. However at some places, thin layers of clay silt are also present within the sand horizon. Clay was mainly found below the depth of $50 \mathrm{~m}$. Three aquifers were identified in the depth range of 0.00 to $12.00 \mathrm{~m}, 15.00$ to $30.00 \mathrm{~m}$ and 41.00 to $47.00 \mathrm{~m} \mathrm{bgl}$, due to presence of clay silt horizons. A mixture of silt with minor clay and kankar separates these aquifers from each other.

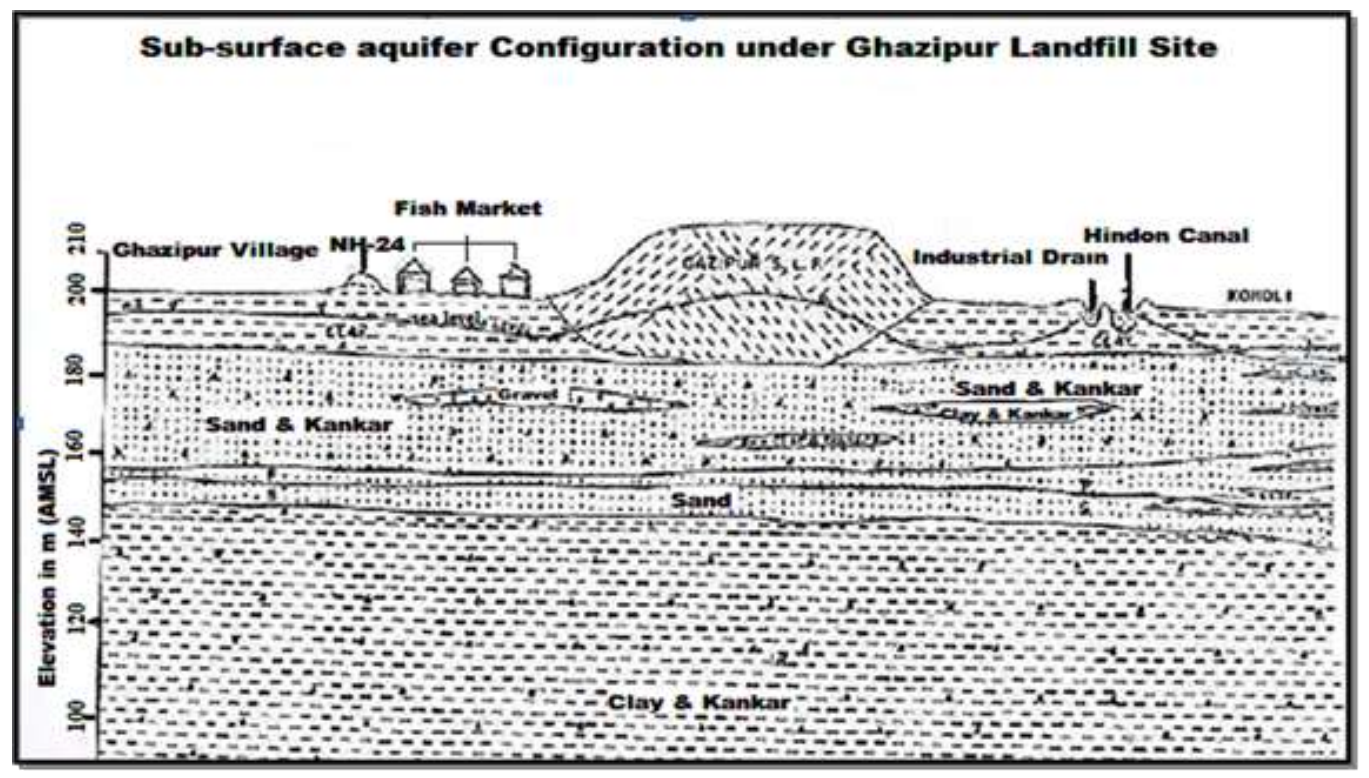

Fig. 2: Sub-surface geological cross section of Ghazipur landfill (Source: Babbar P., 2015)

\section{Materials and Methods}

To assess the groundwater quality, 20 groundwater sampling stations were selected within the area of approximately $2 \mathrm{~km} 2$ at a distance of $0.5 \mathrm{~km}, 1 \mathrm{~km}, 1.5 \mathrm{~km}$ and $2 \mathrm{~km}$ respectively. The samples were collected during post (Nov. 2016) and pre-monsoon (June 2017).

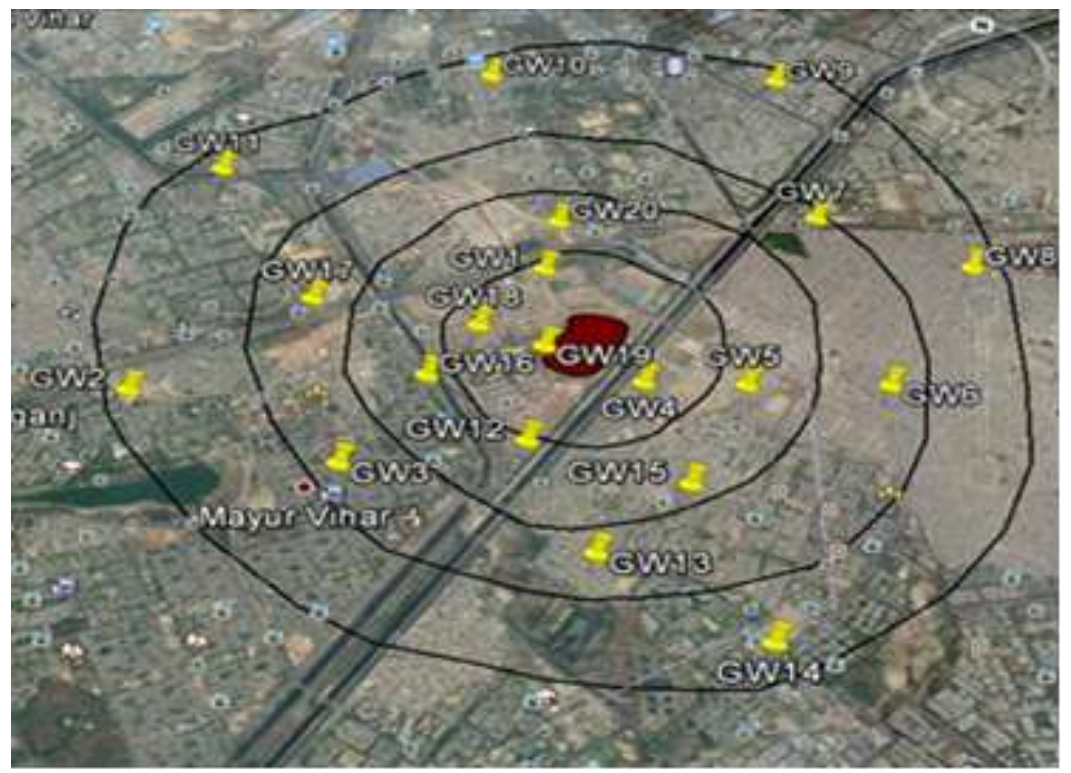

Fig. 3: Groundwater (GW) sampling lo0063ations around Ghazipur landfill site

Physico-chemical analysis of samples for the parameters like $\mathrm{pH}$, Total Dissolved Solids (TDS), chloride, total hardness, total alkalinity, phosphate, fluoride, nitrate and iron were determined as per the Standard Methods 
(APHA, 1998). The two parameters i.e. pH and TDS were measured on the site only. Sampling locations and landfill site are illustrated in Figure 3. The results were used for the calculation of WQI, which finally necessitate evaluating suitability for drinking and human consumption purposes during both the season.

TABLE III: Details of Ground Water (GW) sampling location, near Ghazipur landfill, New Delhi

\begin{tabular}{|c|c|c|c|c|}
\hline \multirow[t]{2}{*}{ Sampling location } & \multirow{2}{*}{$\begin{array}{l}\text { Radial distance from } \\
\text { site }(\mathbf{k m})\end{array}$} & \multirow[t]{2}{*}{ GW location } & \multicolumn{2}{|c|}{ Coordinates } \\
\hline & & & Latitude & Longitude \\
\hline \multicolumn{5}{|l|}{ 0-0.5 Km Buffer Area } \\
\hline SLF* site & 0.07 & 20 & $28^{\circ} 37^{\prime} 35.10^{\prime \prime}$ & $77^{\circ} 19^{\prime} 35.30^{\prime \prime}$ \\
\hline $\mathrm{WtE}^{\$}$ Site & 0.09 & 19 & $28^{\circ} 37^{\prime} 20.60^{\prime \prime}$ & $77^{\circ} 19^{\prime} 27.14^{\prime \prime}$ \\
\hline Radhakrishn Mandir & 0.23 & 18 & $28^{\circ} 37^{\prime} 23.24^{\prime \prime}$ & $77^{\circ} 19^{\prime} 21.19^{\prime \prime}$ \\
\hline C-27, Mulla Colony & 0.28 & 4 & $28^{\circ} 37^{\prime} 13.79^{\prime \prime}$ & $77^{\circ} 19^{\prime} 46.09^{\prime \prime}$ \\
\hline C Block, Dairy Farm & 0.35 & 1 & $28^{\circ} 37^{\prime} 31.68^{\prime \prime}$ & $77^{\circ} 19^{\prime} 18.85^{\prime \prime}$ \\
\hline \multicolumn{5}{|l|}{ 0.5-1 Km Buffer Area } \\
\hline MCD Area, Near Delhi Transco & 0.66 & 12 & $28^{\circ} 37^{\prime} 00.48^{\prime \prime}$ & $77^{\circ} 19^{\prime} 22.88^{\prime \prime}$ \\
\hline 96 A, Sapera Colony & 0.69 & 5 & $28^{\circ} 37^{\prime} 13.21^{\prime \prime}$ & $77^{\circ} 20^{\prime} 04.81^{\prime \prime}$ \\
\hline Dhobi Ghat, Kicharipur & 0.76 & 16 & $28^{\circ} 37^{\prime} 02.34^{\prime \prime}$ & $77^{\circ} 19^{\prime} 13.39^{\prime \prime}$ \\
\hline Rajbir colony & 0.95 & 15 & $28^{\circ} 36^{\prime} 50.92^{\prime \prime}$ & $77^{\circ} 19^{\prime} 50.32^{\prime \prime}$ \\
\hline Block No. 8, Khicharipur & 1.08 & 17 & $28^{\circ} 37^{\prime} 10.54^{\prime \prime}$ & $77^{\circ} 18^{\prime} 53.25^{\prime \prime}$ \\
\hline \multicolumn{5}{|l|}{ 1-1.5 Km Buffer Area } \\
\hline GD Colony, Gharoli Extension & 1.11 & 13 & $28^{\circ} 36^{\prime} 45.77^{\prime \prime}$ & $77^{\circ} 19^{\prime} 50.47^{\prime \prime}$ \\
\hline Shani Bazar, Near Subhash Park & 1.25 & 7 & $28^{\circ} 37^{\prime} 39.10^{\prime \prime}$ & $77^{\circ} 20^{\prime} 31.90^{\prime \prime}$ \\
\hline Khora Colony & 1.31 & 6 & $28^{\circ} 37^{\prime} 13.17^{\prime \prime}$ & $77^{\circ} 20^{\prime} 31.04^{\prime \prime}$ \\
\hline Block 16, Kalyanpuri Park & 1.40 & 3 & $28^{\circ} 36^{\prime} 55.46^{\prime \prime}$ & $77^{\circ} 18^{\prime} 48.78^{\prime \prime}$ \\
\hline Sec- 62A, Makanpur Colony & 1.68 & 8 & $28^{\circ} 37^{\prime} 54.32^{\prime \prime}$ & $77^{\circ} 20^{\prime} 42.56^{\prime \prime}$ \\
\hline \multicolumn{5}{|l|}{ 1.5-2 Km Buffer Area } \\
\hline Anand Vihar, Kaushambi & 1.92 & 10 & $28^{\circ} 38^{\prime} 36.10^{\prime \prime}$ & $77^{\circ} 19^{\prime} 28.77^{\prime \prime}$ \\
\hline New Kondli village & 1.98 & 14 & $28^{\circ} 36^{\prime} 18.49^{\prime \prime}$ & $77^{\circ} 19^{\prime} 58.00^{\prime \prime}$ \\
\hline Sec-5, Vaishali & 2.03 & 9 & $28^{\circ} 38^{\prime} 38.34^{\prime \prime}$ & $77^{\circ} 20^{\prime} 30.50^{\prime \prime}$ \\
\hline Shani Mandir, I.P Extension & 2.09 & 11 & $28^{\circ} 38^{\prime} 08.69^{\prime \prime}$ & $77^{\circ} 18^{\prime} 31.50^{\prime \prime}$ \\
\hline B Block, Mayur Vihar Phase II & 2.13 & 2 & $28^{\circ} 37^{\prime} 12.09^{\prime \prime}$ & $77^{\circ} 18^{\prime} 11.84^{\prime \prime}$ \\
\hline
\end{tabular}

\$Waste to Energy

*Sanitary Landfill site

\subsection{Water Quality Index (WQI):}

Water Quality Index has emerged as a standard tool to assess the water quality of ground and surface water (Yadav et al., 2015 and Krishnan et al., 2016). The main purpose of WQI is to convert a complex set of water quality data into logical and easily usable information, so that even common man can easily understand the water quality (Akoteyon et al., 2011; Balan et al., 2012). Following steps are followed for the calculation of WQI (Ramakrishnaiah et al., 2009; Vasanthavigar et al., 2010):

In the first step, each parameter has been assigned a weight (wi) according to its relative importance in the overall water quality for drinking purposes as compared with values of Bureau of Indian Standards (BIS 10500:1991). The relative weight of each chemical parameter is shown in table 4.

In the second step, following equation is used to calculate the relative weight (Wi):

$$
W_{i}=\frac{W_{i}}{\sum_{i=1}^{n} W_{i}}
$$

where, wi $=$ weight of each parameter, $\mathrm{Wi}=$ relative weight, $\mathrm{n}=$ number of parameters

In the third step, to derive the quality rating scale $\left(\mathrm{q}_{\mathrm{i}}\right)$, concentration of each chemical parameter in each water sample has been divided by its respective standard according to the BIS 10500 (1991) guidelines and finally the outcome is multiplied by 100 :

$\mathrm{q}_{\mathrm{i}}=\left(\mathrm{C}_{\mathrm{i}} / \mathrm{S}_{\mathrm{i}}\right) \times 100$

where, $\mathrm{q}_{\mathrm{i}}=$ quality rating,

$\mathrm{C}_{\mathrm{i}}=$ concentration of each chemical parameter in each water sample $(\mathrm{mg} / \mathrm{l})$ 
$\mathrm{S}_{\mathrm{i}}=$ Indian drinking water standard for each chemical parameter $(\mathrm{mg} / \mathrm{l})$

Now, the SI (Sub-Index) is determined for each chemical parameter and finally used to calculate the WQI as per the below equation:

$\mathrm{SI}_{\mathrm{i}}=\mathrm{W}_{\mathrm{i}} \times \mathrm{q}_{\mathrm{i}}$

$\mathrm{WQI}=\sum \mathrm{SI}_{\mathrm{i}}$

Where, $\mathrm{SI}_{\mathrm{i}}=$ sub-index of $\mathrm{i}^{\text {th }}$ parameter, $\mathrm{q}_{\mathrm{i}}=$ rating based on concentration of $\mathrm{i}^{\text {th }}$ parameter, $\mathrm{n}=$ number of parameters

TABLE IV: Relative Weight of Chemical Parameters of Ground Water

\begin{tabular}{lccc}
\hline \multicolumn{1}{c}{$\begin{array}{c}\text { Chemical parameters } \\
(\mathbf{m g} / \mathbf{l})\end{array}$} & $\begin{array}{c}\mathbf{S}_{\mathbf{i}} \\
(\mathbf{B I S ~ S t a n d a r d ~ 1 0 5 0 0})\end{array}$ & Weight $\left(\mathbf{w}_{\mathbf{i}}\right)$ & $\begin{array}{c}\text { Relative weight } \\
\left(\mathbf{W}_{\mathbf{i}}\right)\end{array}$ \\
\hline $\mathrm{pH}$ & $6.5-8.5$ & 4 & 0.1429 \\
Total dissolved solids (TDS) & 500 & 4 & 0.1429 \\
Total hardness (TH) & 300 & 2 & 0.0714 \\
Total Alkalinity (TA) & 300 & 2 & 0.0714 \\
Chloride (as Cl) & 250 & 3 & 0.1071 \\
Fluoride (as F) & 1 & 4 & 0.1429 \\
Nitrate (as NO $\left.\mathrm{NO}_{3}\right)$ & 45 & 5 & 0.1786 \\
Total Iron & 0.1 & 4 & 0.1429 \\
\hline
\end{tabular}

\section{Results and Discussion}

WQI has been estimated from the analysis of various water quality parameters. The statistical summary of the various groundwater samples collected from the surrounding area of Ghazipur landfill site during pre and post monsoon season has been illustrated in Table 5 as follow.

TABLE V: WQI estimates of Ground Water quality near Ghazipur landfill site, New Delhi.

\begin{tabular}{lcccc}
\hline GW Samples & WQI - Post Monsoon & WQI- Pre Monsoon & Average WQI & Water Quality \\
\hline GW1 & 164.95 & 139.89 & 152.42 & Poor \\
GW2 & 101.29 & 86.86 & 94.07 & Good \\
GW3 & 107.43 & 102.01 & 104.72 & Poor \\
GW4 & 107.32 & 104.59 & 105.95 & Poor \\
GW5 & 75.53 & 106.73 & 91.13 & Good \\
GW6 & 143.19 & 150.60 & 146.90 & Poor \\
GW7 & 169.56 & 155.33 & Poor \\
GW8 & 141.11 & 245.07 & 242.19 & Very poor \\
GW9 & 239.31 & 238.59 & 238.68 & Very poor \\
GW10 & 282.30 & 281.68 & Very poor \\
GW11 & 345.45 & 343.11 & Very poor \\
GW12 & 238.77 & 174.84 & 166.54 & Poor \\
GW13 & 281.07 & 138.01 & 125.56 & Poor \\
GW14 & 340.78 & 145.74 & 120.61 & Poor \\
GW15 & 158.23 & 114.44 & 93.51 & Good \\
GW16 & 113.11 & 123.86 & 123.80 & Poor \\
GW17 & 95.49 & 90.34 & 70.41 & Good \\
GW18 & 72.58 & 116.55 & 104.51 & Poor \\
GW19 & 123.74 & 132.94 & 126.43 & Poor \\
GW20 & 50.47 & 134.28 & 134.85 & Poor \\
\hline
\end{tabular}

The Table 5 shows that the WQI of 20 groundwater samples during pre monsoon ranged from 49.30 (GW2) to 244.83 (GW10) whereas the WQI for post monsoon groundwater samples ranged from 36.06 (GW17) to 239.40 (GW10). The average WQI value in the study area ranged from 46.54 to 242.12. The Table 6 illustrates the water quality classification, based on WQI value (table 5). Water quality can be categorized into five 
different classes which can vary from "excellent water quality" to "water unsuitable for drinking". It also shows the percentage of water samples that falls under different quality.

TABLE VI: Classification of Water Quality Based on WQI Value (Ramakrishnaiah et al., 2009, Vasanthavigar et al., 2010)

\begin{tabular}{lcc}
\hline \multicolumn{1}{c}{ WQI Value } & Water Quality & Percentage of GW samples \\
\hline$<50$ & Excellent water quality & 00 \\
$50-100$ & Good water quality & 20 \\
$100-200$ & Poor water quality & 60 \\
$200-300$ & Very poor water quality & 20 \\
$>300$ & Water unsuitable for drinking & 00 \\
\hline
\end{tabular}

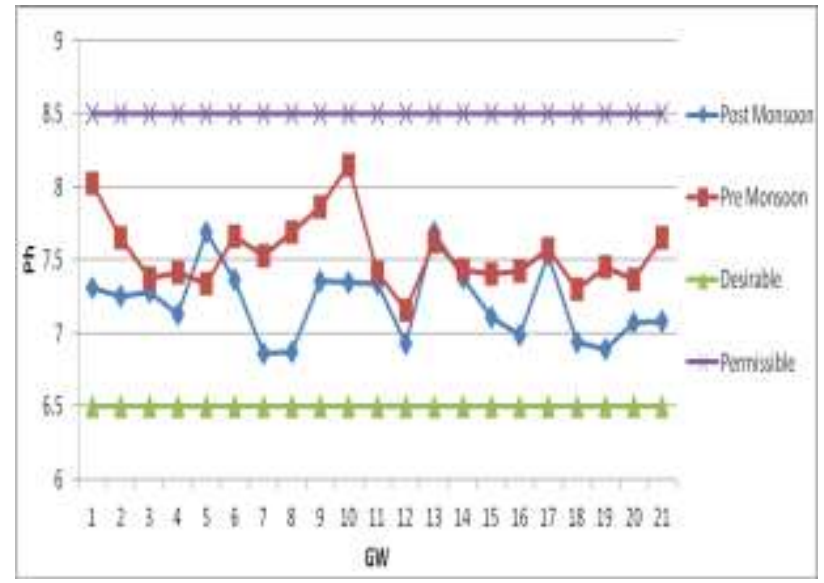

Fig. 4 (a)

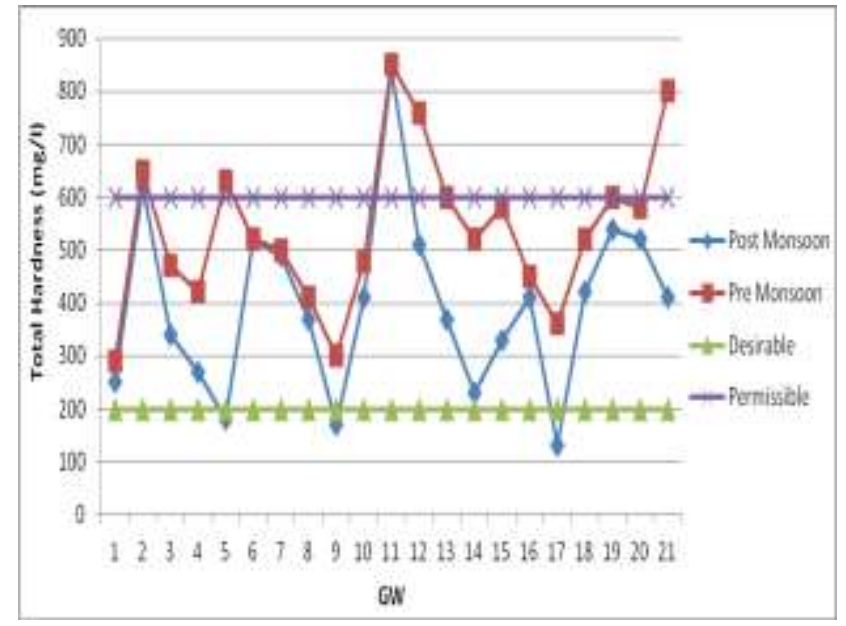

Fig. 4 (c)

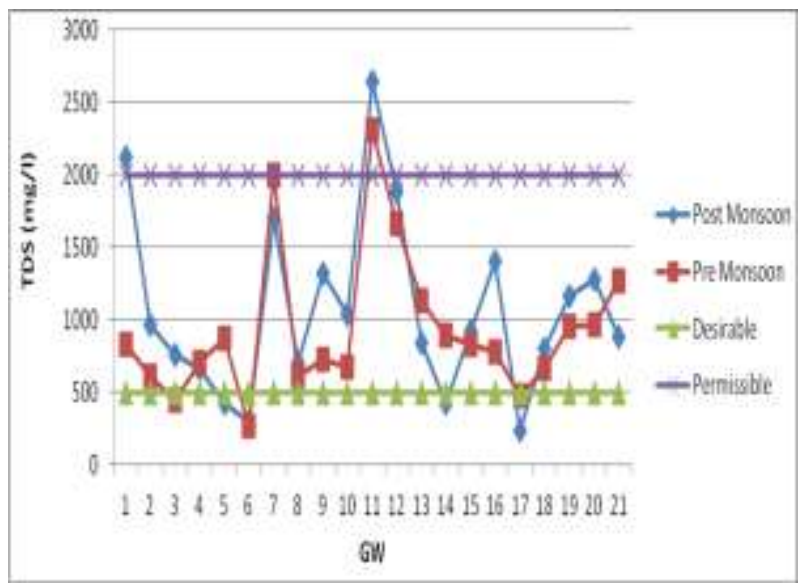

Fig. 4 (b)

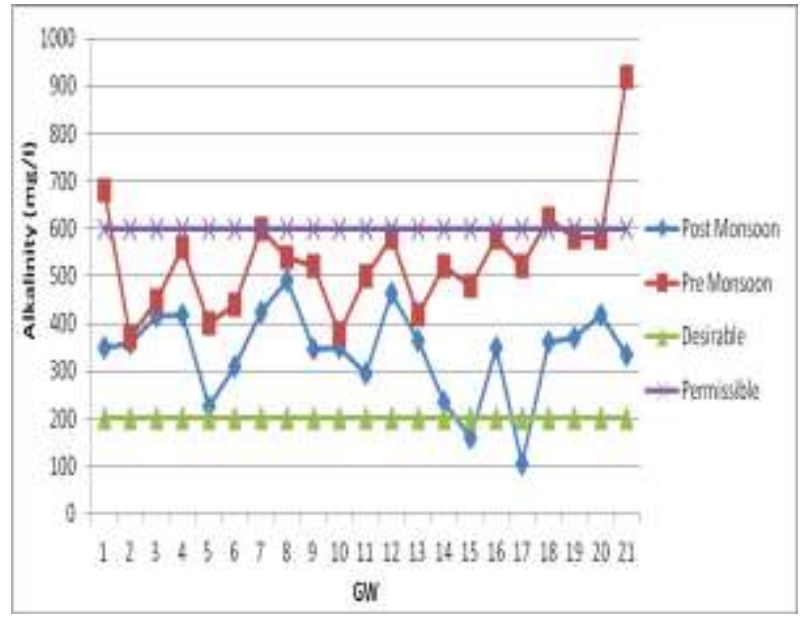

Fig. 4 (d) 


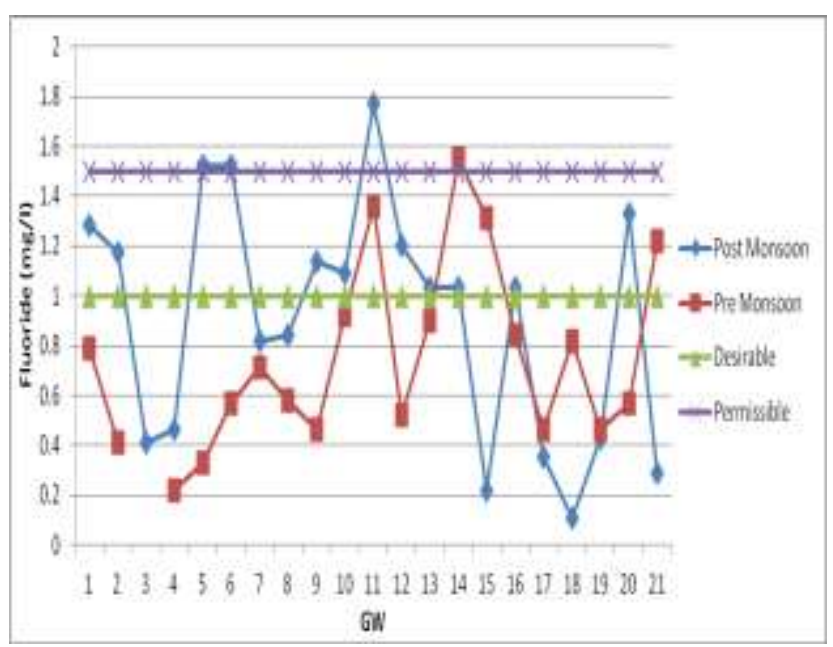

Fig. 4 (e)

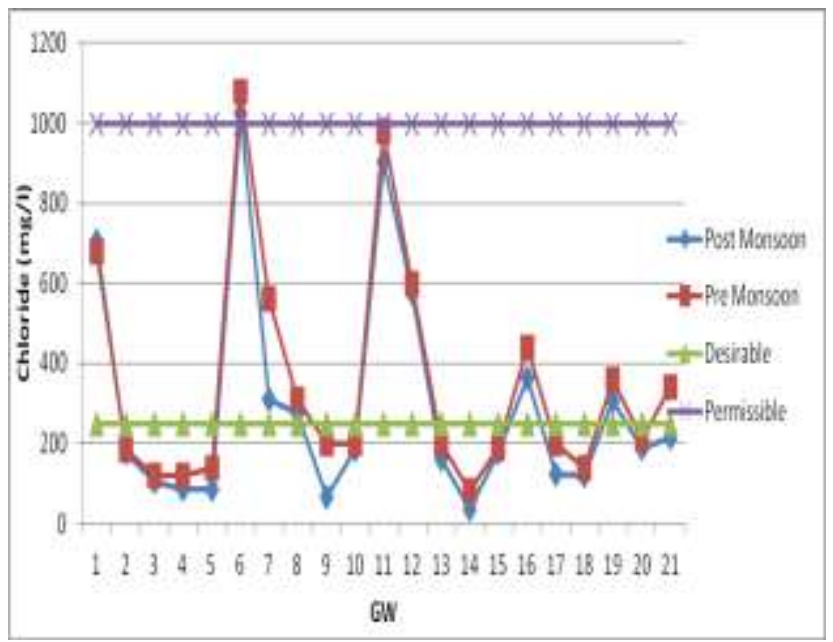

Fig. 4 (g)

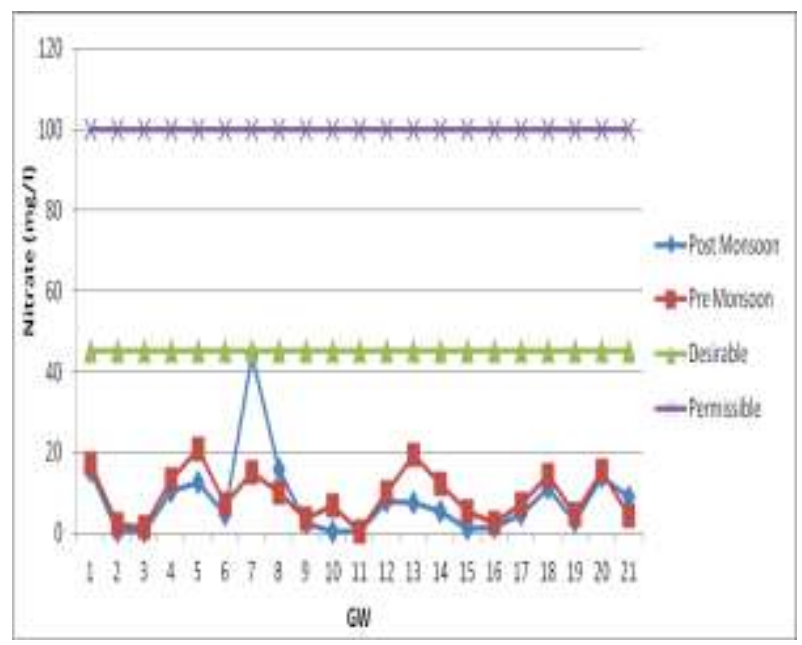

Fig. 4 (f)

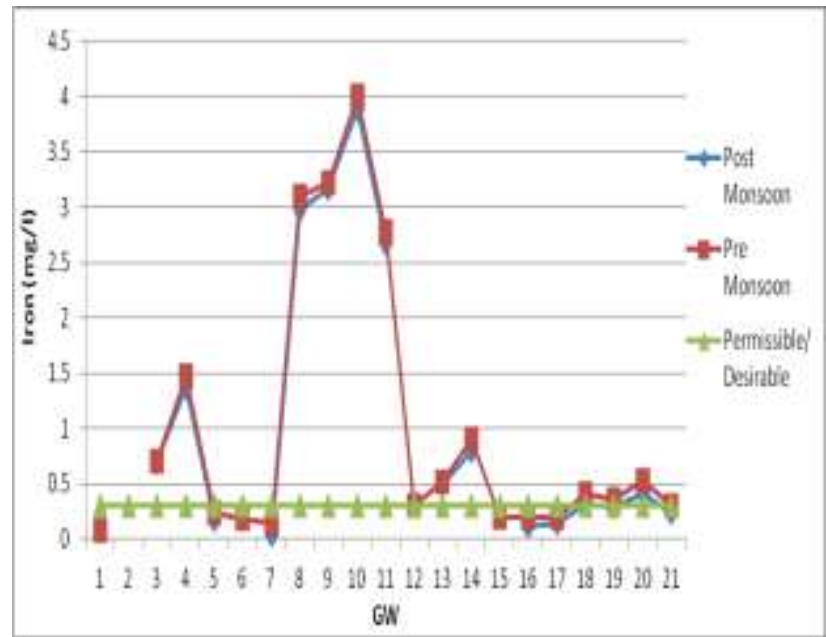

Fig. 4 (h)

Fig. 4: Figures of different parameters representing, a) pH, b) TDS, c) Hardness, d) Alkalinity, e) Fluoride, f) Nitrate, g) Chloride, h) Iron vis-a-vis BIS standards

The $\mathrm{pH}$ value represents the extent of acidity or alkalinity of a given water sample. The min. and max $\mathrm{pH}$ values of samples for pre monsoon season were 7.16 and 8.15 respectively and 6.86 and 7.69 for post monsoon season. The average $\mathrm{pH}$ values for pre $\&$ post monsoon were within the BIS prescribed limits i.e. 6.5 - 8.5. The $\mathrm{pH}$ values for most of the groundwater samples were in the range of 7 to 8 , which shows that the groundwater in the study area is slightly alkaline in nature.

Measurement of TDS is a direct representation of the total dissolved solid particles present in a sample. The concentration of TDS ranged from 266mg/l to $2310 \mathrm{mg} / \mathrm{l}$ during pre monsoon and from 240 to $2640 \mathrm{mg} / \mathrm{l} \mathrm{during}$ post monsoon, which was mostly exceeding the BIS desirable limit of $500 \mathrm{mg} / \mathrm{l}$. The highest concentration of TDS during post monsoon was found to be $2120 \mathrm{mg} / \mathrm{l}$ at GW1, a sampling location nearest to landfill site while for the pre monsoon season, the highest concentration of TDS $(2310 \mathrm{mg} / \mathrm{l})$ was found at GW11. This indicates that there is a presence of inorganic material in the groundwater. Olaniya (Olaniya et al., 1977) also found the indications of groundwater pollution in the vicinity of landfill sites due to a higher concentration of TDS in the groundwater samples collected. Groundwater with high TDS is usually not hazardous to human health however the high concentration of TDS may be harmful to persons already affected with kidney and heart diseases (Gupta et al., 2004) and the same may also cause laxative or constipation effects to human beings (Kumaraswamy, 1999). 
Hardness mainly caused due to the presence of cations of calcium and magnesium. The concentration of total hardness ranges from $290 \mathrm{mg} / \mathrm{l}$ to $850 \mathrm{mg} / \mathrm{l}$ in pre monsoon and $130 \mathrm{mg} / \mathrm{l}$ to $840 \mathrm{mg} / \mathrm{l}$ in the post monsoon season respectively. The hardness values of most of the ground water samples for pre-monsoon season were found to be higher than the standard desirable limit i.e. $200 \mathrm{mg} / \mathrm{l}$. At some of the sampling locations viz. GW2, GW5, GW11, GW12, GW13 and GW19, the hardness values were exceeding the permissible limit (600mg/l) of BIS standards as well. During post monsoon season, the hardness values were found to be higher than desirable limit except for three locations i.e. at GW5, GW9, and GW17. According to Vasanthavigar (Vasanthavigar et al., 2010) high values of hardness in post-monsoon were contributed by dissolution of salts and minerals through infiltration of rainwater into the groundwater system. During post monsoon season, the maximum value of hardness i.e. $840 \mathrm{mg} / \mathrm{l}$ was found at GW11 as against the permissible limit of $600 \mathrm{mg} / \mathrm{l}$. It may be inferred from the figure 4 (c) that most of the groundwater samples in the study area are hard in nature. The alkalinity of groundwater in the study area was ranging from $370 \mathrm{mg} / 1$ to $680 \mathrm{mg} / \mathrm{l}$ and $105 \mathrm{mg} / \mathrm{l}$ to $490 \mathrm{mg} / \mathrm{l}$ during pre and post monsoon seasons respectively. All the sites have alkalinity above the BIS standards of desirable limit (200mg/l) and alkalinity at GW1 has the maximum value of $680 \mathrm{mg} / \mathrm{l}$ in pre monsoon which exceeded the permissible limit of BIS as well.

The fluoride concentration was ranging from $0.22 \mathrm{mg} / \mathrm{l}$ to $1.55 \mathrm{mg} / \mathrm{l}$ during pre monsoon and $0.11 \mathrm{mg} / \mathrm{l}$ to $1.77 \mathrm{mg} / \mathrm{l}$ during post monsoon season respectively. The maximum level of fluoride i.e. $1.55 \mathrm{mg} / \mathrm{l}$ during pre monsoon was observed at GW14 which exceeded the standard permissible limit of $1.5 \mathrm{mg} / \mathrm{l}$. During post monsoon season, $45 \%$ of groundwater samples were found to have fluoride concentration beyond the desirable limit of 1mg/l. Such samples are of GW1, GW2, GW9, GW10, GW12, GW13, GW14, GW16, and GW20. Around $15 \%$ of groundwater samples exceeded the permissible limit of fluoride $(1.5 \mathrm{mg} / \mathrm{l})$ and such samples are of GW5, GW6 and GW11.

The nitrate concentration varied from $0.52 \mathrm{mg} / 1$ to $20.86 \mathrm{mg} / \mathrm{l}$ during the pre monsoon season and $0.25 \mathrm{mg} / 1$ to $43.97 \mathrm{mg} / \mathrm{l}$ during post monsoon season. The nitrate value for the study area was within the BIS standard permissible limit i.e. $45 \mathrm{mg} / \mathrm{l}$ for all groundwater samples. The highest value of nitrate was observed at GW7 location during the post monsoon season.

A high concentration of Chloride in groundwater may be indicating its pollution and contamination (Loizidou et al., 1993). Chloride is the most commonly found element in rocks in different forms. It has high affinity towards sodium and its concentration is high in groundwater, where the temperature is high and rainfall is less. Soil porosity and permeability also play major role in increasing the chlorides concentration (Chadha, 1999). The chloride concentrations in groundwater samples varied from $80 \mathrm{mg} / \mathrm{l}$ to $1080 \mathrm{mg} / \mathrm{l} \mathrm{during}$ pre monsoon and 35 to $1025 \mathrm{mg} / \mathrm{l}$ during post monsoon. The chloride concentration in the study area was found within the standard permissible level $(1000 \mathrm{mg} / \mathrm{l})$, except at GW6 where it was $1080 \mathrm{mg} / \mathrm{l}$ for pre monsoon and $1025 \mathrm{mg} / \mathrm{l}$ for post monsoon season. Increased Chloride level in groundwater may be harmful for persons suffering from diseases related to kidney and heart (WHO, 1997).

The iron concentration in pre monsoon was varying from $0.08 \mathrm{mg} / \mathrm{l}$ to $4 \mathrm{mg} / \mathrm{l}$ and $0.04 \mathrm{mg} / \mathrm{l}$ to $3.89 \mathrm{mg} / \mathrm{l}$ in post monsoon. During pre monsoon, 12 groundwater samples (60\% of the total samples) were having iron concentration beyond the desirable limit. During post monsoon season, iron was not traceable at some locations i.e. at GW1, GW2, GW6, GW12 and GW15, however at 9 locations (45\% of sample size), it exceeded the standard desirable limit $(0.3 \mathrm{mg} / \mathrm{l})$. This may be an indication of presence of iron and steel scrap in the garbage being dumped at site or may be its direct dumping at the landfill site of Ghazipur.

\section{Conclusions}

The high concentration of TDS, hardness, alkalinity, chloride, fluoride and iron in groundwater in close proximity to landfill site has polluted the groundwater and deteriorated its quality for drinking and other domestic purposes. WQI is a standard tool for assessment and management of water quality. According to WQI values, approximately 60 percent of groundwater samples had poor quality of water, whereas 20 percent falls 
under the category very poor quality water. Only 20 percent of groundwater samples in the study area had good quality of water. High values of hardness, magnesium and chloride indicate leaching and infiltrations from upper soil layers and anthropogenic pollution. It can be concluded that landfill site had impact on groundwater quality in the surrounding area of Ghazipur landfill, as there is no other natural and anthropogenic source other than landfill site which can be responsible for the presence of higher concentration of these pollutants. From the results, it can be concluded that the groundwater treatment is a necessity, prior to drinking or for domestic consumption of water. It is suggested that the surrounding area of Ghazipur landfill should be protected from further contamination and also to minimize associated adverse impacts.

\section{Acknowledgement}

The authors are grateful to IL \& FS Environment Infrastructure Services Limited for giving support during the study period. We are thankful to Dr. P. D. Grover, Senior Consultant, IL \& FS Environment Infrastructure Services Limited, for his valuable suggestions and support. We are also thankful to Dr. N. B. Mazumdar, Director, Sulabh International Social Service Organization, Delhi for necessary help from time to time.

\section{References}

[1] Bhide, A.D., Shekdar, A.V., 1998. Solid waste management in Indian urban centers. International Solid Waste Association Times (ISWA), (1), 26-28.

[2] Longe, E. O. and Balogun, M. R., 2010. Groundwater quality assessment near a municipal landfill, Lagos, Nigeria. Research Journal of Applied Sciences, Engineering and Technology, 2(1), 39-44.

[3] Kurniawan, T.A., Chan, G.Y.S., Lo, W.H., Babel, S., 2006. Physicochemical treatment techniques for wastewater laden with heavy metals. Chemical Engineering Journal, 118, 83-98.

[4] Mor, S., Ravindra, K., Dahiya, R.P. and Chandra, A., 2006. Leachate Characterization and assessment of groundwater pollution near municipal solid waste landfill site. Environmental Monitoring and Assessment, 118, 435-456.

[5] Sharma, D. and Kansal, A., 2011. Water quality analysis of River Yamuna using water quality index in The National capital territory, India (2000-2009). Applied Water Science, 1 (3-4), 147-157.

[6] Sebastian, J. and Yamakanamardi, S.M., 2013. Assessment of water quality index of Cauvery and Kapila Rivers and at their confluence. International Journal of Lakes and Rivers, 6(1), 59-67.

[7] Jha, M.K., Sondhi, O.A.K., Pansare, M., 2003. Solid waste management - a case study. Indian Journal of Environmental Protection, 23 (10), 1153-1160.

[8] Taylor, R. and Allen, A., 2006. Waste Disposal and Landfill: Potential Hazards and Information Needs. In: WHO, World Health Organization (Eds.), Protecting Groundwater for Health: Managing the Quality of Drinking Water Resources, 339-360.

[9] Abu-Rukah, Y., Al-Kofahi, O., 2001. The assessment of the effect of landfill leachate on groundwater quality-a case study, El-Akader landfill site, North Jordan. Journal of Arid Environments, 49, 615-630.

[10] Babbar, P., 2015. Feasibility and Design of Tube-wells for Drinking Water supply in and around the Landfill Sites: A case study on Ghazipur landfill site, Delhi.

[11] Central Ground Water Board, New Delhi \& Central Pollution Control Board-Status of Ground Water quality and Pollution Aspects in NCT-Delhi, 2000.

[12] APHA (American Public Health Association), 1998. Standard Methods for the Examination of Water and Wastewater.

[13] Yadav, K.K., Gupta, N., Kumar, V., Sharma, S., Arya, S., 2015. Water quality assessment of Pahuj River using water quality index at Unnao Balaji, M.P., India. International Journal of Science: Basic and Applied Research, 19(1), 241250.

[14] Krishnan, G., Singh, S., Singh, R.P., Ghosh, N.C., and Khanna, A., 2016. Water quality index of groundwater of Haridwar District, Uttarakhand, India. Water and Energy International, 58(10), 55-58. 
[15] Akoteyon, I.S., Omotayo, A.O., Soladoye, O., Olaoye, H.O., 2011. Determination of water quality index and suitability of urban river for municipal water supply in Lagos, Nigeria. European Journal of Scientific Research. 54(2), 263-271.

[16] Balan, I.N., Shivakumar, M., Kumar, P.D.M., 2012. An assessment of groundwater quality using water quality index in Chennai, Tamil Nadu, India. Chronicals of Young Scientists, 3(2), 146-150.

[17] Ramakrishnaiah, C. R., Sadashivaiah, C., and Ranganna, G., 2009. Assessment of Water Quality Index for the groundwater in Tumkur Taluk, Karnataka state, India. E-Journal of Chemistry, 6(2), 523-530.

[18] Vasanthavigar, M., Srinivasamoorthy, K., Vijayaragavan, K., Rajiv Ganthi, R., Chidambaram, S., Anandhan, P., Manivannan, R. and Vasudevan, S. 2010. Application of water quality index for groundwater quality assessment: Thirumanimuttar sub-basin, Tamilnadu, India. Environmental Monitoring and Assessment, 171, 595-609.

[19] BIS (Bureau of Indian standards) 10500. 1991. Indian Standard drinking water-specification (1st revision).

[20] Olaniya, M.S., and Saxena, K.L., 1977. Ground water pollution by open refuse dumps at Jaipur. Indian Journal of Environment Health, 19(3), 176-188.

[21] Gupta, S., Kumar, A., Ojha, C. K., and Singh, G. 2004. Journal of Environmental Science and Engineering, 46(1), 7478.

[22] Kumaraswamy, N., 1999. Physico-Chemical analysis of groundwater of selected area in city, Tamilnadu, India. Journal of Pollution Research, 10(1), 13-20.

[23] Loizidou, M. and Kapetanios, E., 1993. Effect of leachate from landfills on underground water quality. Science of the Total Environment. 128, 69-81.

[24] Chadha, D.K., 1999. A proposed new diagram for geochemical classification of natural waters and interpretation of chemical data, Journal of Hydrology, 7(5), $431-439$. 